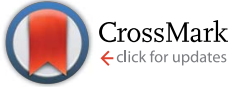

Cite this: Energy Environ. Sci., 2014, 7, 2792

\title{
Cost analysis of roll-to-roll fabricated ITO free single and tandem organic solar modules based on data from manufacture $\uparrow$
}

\author{
Florian Machui, ${ }^{\text {a }}$ Markus Hösel, ${ }^{\mathrm{b}}$ Ning Li, ${ }^{a}$ George D. Spyropoulos, ${ }^{a}$ Tayebeh Ameri, ${ }^{a}$ \\ Roar R. Søndergaard, ${ }^{\mathrm{b}}$ Mikkel Jørgensen, ${ }^{\mathrm{b}}$ Arnulf Scheel, ${ }^{\mathrm{C}}$ Detlef Gaiser, ${ }^{\mathrm{c}}$ Kilian Kreul, ${ }^{\mathrm{d}}$ \\ Daniel Lenssen, ${ }^{d}$ Mathilde Legros, ${ }^{e}$ Noëlla Lemaitre, ${ }^{e}$ Marja Vilkman, ${ }^{f}$ Marja Välimäki, ${ }^{f}$ \\ Sirpa Nordman, ${ }^{f}$ Christoph J. Brabec ${ }^{a}$ and Frederik C. Krebs ${ }^{b}$
}

\begin{abstract}
We present a cost analysis based on state of the art printing and coating processes to fully encapsulated, flexible ITO- and vacuum-free polymer solar cell modules. Manufacturing data for both single junctions and tandem junctions are presented and analyzed. Within this calculation the most expensive layers and processing steps are identified. Based on large roll-to-roll coating experiments the exact material consumptions were determined. In addition to the data for the pilot scale experiment presented here, projections to medium and large scale scenarios serve as a guide to achieve cost targets of $5 €$ ct per $W_{p}$ in a detailed material and cost analysis. These scenarios include the replacement of cost intensive layers, as well as process optimization steps. Furthermore, the cost structures for single and tandem devices are listed in detail and discussed. In an optimized model the material costs drop below $10 €$ per $\mathrm{m}^{2}$ which proves that OPV is a competitive alternative to established power generation technologies.
\end{abstract}

Received 17th April 2014

Accepted 3rd June 2014

DOI: $10.1039 / c 4 e e 01222 d$

www.rsc.org/ees

\begin{abstract}
Broader context
Among the emerging solar cell technologies organic photovoltaics (OPVs) have gained enormous attraction due to their various advantages in applications, i.e. light weight, semitransparency, tunable band gaps and colors. The decisive criteria for a market entrance of a new renewable technology to become a successful competitor are the costs and cost potential which are influenced by their processing technique. Currently processing of photovoltaic devices is mainly done in non-continuous batch-to-batch processes at elevated temperatures. OPVs offer the advantage of high throughputs due to their compatibility to continuous rollto-roll coating techniques. This leads to the potential to dramatically reduce the processing costs in comparison to mature photovoltaic technologies. One of the drawbacks of OPVs is their lower device efficiency in comparison to inorganic materials. The use of tandem devices offers the potential to overcome the limiting device efficiency of OPVs which requires the printing of several additional layers. Based on state of the art processing costs the exact material consumptions for single and tandem devices were determined and compared. We demonstrate that OPV is a competitive energy technology which is not only compatible with inorganic PV, but also with other energy technologies such as wind, hydro and biomass.
\end{abstract}

\begin{abstract}
${ }^{a}$ Materials for Electronics and Energy Technology (i-MEET), Department of Material Science and Engineering, Friedrich-Alexander University Erlangen-Nürnberg, Martensstrasse 7, 91058 Erlangen, Germany. E-mail: forian.machui@ww. uni-erlangen.de; Fax: +49-(0)9131/85-28495; Tel: +49-(0)9131/85-27717

${ }^{b}$ Department of Energy Conversion and Storage, Technical University of Denmark, Frederiksborgvej 399, DK-4000 Roskilde, Denmark

${ }^{c}$ Heraeus Precious Metals GmbH \& Co. KG, Electronic Materials Division, Chempark Leverkusen Bldg. B202, 51368 Leverkusen, Germany

${ }^{d}$ DELO Industrial Adhesives, DELO-Allee 1, 86949 Windach, Germany

${ }^{e}$ CEA, LITEN, INES Campus, F-73375 Le Bourget du Lac, France

${ }^{f} V T T$ Technical Research Centre of Finland, Printed and hybrid functionalities, P.O.Box 1000, FI-02044 VTT, Finland
\end{abstract}

$\dagger$ Electronic supplementary information (ESI) available. See DOI: $10.1039 / \mathrm{c} 4 \mathrm{ee} 01222 \mathrm{~d}$

\section{Introduction}

An increasing world population combined with increasing living standards intensifies the demand for low cost, clean and renewable energy sources. Due to air pollution and carbon dioxide emissions from combustion of fossil fuels the need for regenerative energy sources is becoming a compelling necessity. Organic solar cells (OSCs) are often discussed as an alternative to inorganic photovoltaics, due to their advantages of light weight, flexible substrates and tunable band gaps. However, the most persuasive reason is the promise of a low cost technology, competitive to silicon and thin layer products. The cost potential of organic photovoltaics (OPVs) originates from the low temperature and solution based processing which enables the use of roll-to-roll (R2R) based production methods at high speed and high throughput. Different film application techniques have been demonstrated which can be used in a R2R 
process. ${ }^{1-3}$ Compared to the inorganic solar cells the drawbacks of OPVs are the lower device efficiency and shorter module lifetime. In order to compete with inorganic photovoltaics (PVs) a dramatically lower cost of OPVs is necessary. A smart approach to overcome the limiting device efficiency of OPVs is the use of tandem cells. Dennler et al. showed the advantages of this concept which were later also reviewed in other publications. ${ }^{4-7}$ The tandem architecture comprises two different series or parallel connected sub-cells, with active layer materials with complementary absorption spectra. In tandem devices the intermediate layer is one of the crucial processing steps, building an ohmic contact (ideally lossless) between the two sub-cells. The use of poly(3,4-ethylenedioxythiophene) doped with polystyrene sulfonate (PEDOT:PSS) and aluminium doped $\mathrm{ZnO}$ as an efficient and robust intermediate layer was demonstrated. ${ }^{\mathbf{8}, 9}$ This layer combination is compatible with R2R processing which is mandatory for an upscaling process. Currently the record efficiencies are achieved with lab scale devices with active areas below $1 \mathrm{~cm}^{2}$, using materials which are synthesized on a very small scale (typically in batches well below $1 \mathrm{~g}$ ). Furthermore, often electrodes, interfaces and barrier materials are used which are cost intensive and not compatible with a R2R process or true to the vision of a low cost technology.

For a cost analysis to be useful as a research tool the currently utilized materials and processes are considered. Different publications already investigated the cost analysis of an OPV technology. ${ }^{\mathbf{1 0 - 1 5}}$ Often in these calculations cost intensive layers were included and tandem devices were not considered. In this manuscript we focus on calculations based on real data determined by a R2R process and scale up effects including experts' opinions. Further, comparisons between single and tandem devices are evaluated. It is important that the input is

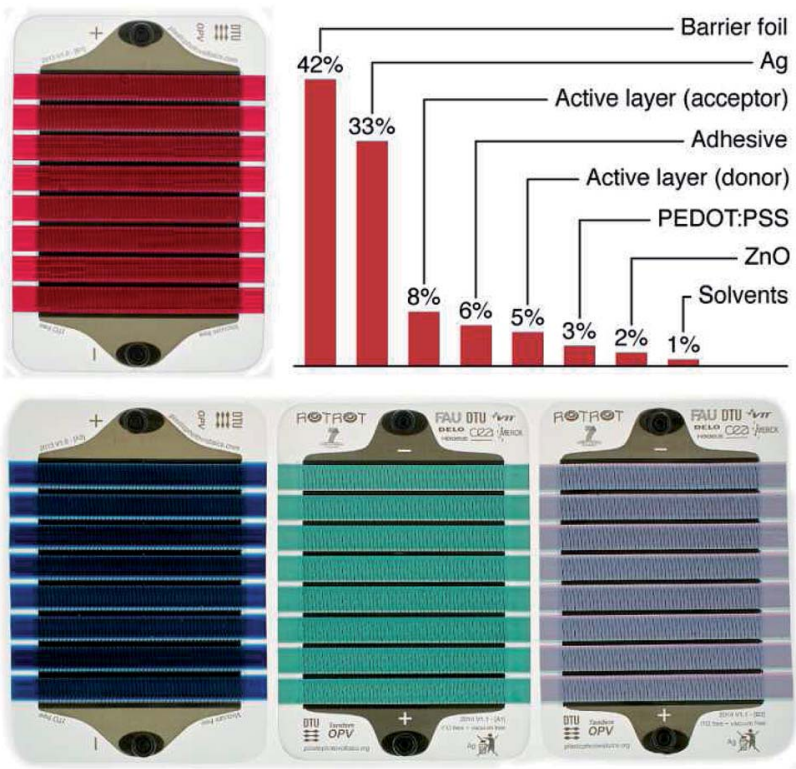

Fig. 1 Illustration of the current freeOPV (top left) along with the present cost structure (top right). Next generation materials are shown in both single junction freeOPV (left) and tandem freeOPV (middle and right).

real data with few (or no) assumptions. The accuracy of the starting point is essential for an accurate extrapolation to larger scenarios. In Fig. 1 we show the cost structure of the wellestablished freeOPVs along with photographs of both single junction and tandem junction modules. ${ }^{27}$ This is followed by the identification of cost intensive layers, including cost reducing scale up effects which are then used to direct the development of both materials and processing methods. The vision of the end product and the process leading to it has to be maintained at all times. In the case of OPVs this implies that the production and materials have to be fully compatible with R2R processing.

\section{State of the art - lab scale}

Solution processed state of the art devices currently achieve power conversion efficiencies (PCE) of $10.7 \%$ in single and $10.6 \%$ in tandem devices. ${ }^{16,17}$ These are, like most of the currently solar cell data, based on a lab scale processes and devices with an active layer $<1 \mathrm{~cm}^{2}$, using indium tin oxide (ITO) as a front electrode and an evaporated counter electrode. Further, for high performance usually glass is used as the substrate. Fig. (2a) shows an often used layer stack for OPV cells on the lab scale. Different publications have shown that ITO is one of the most cost and energy intensive layers within the solar stack. ${ }^{13,18,19}$ The cost model of Azzopardi et al. ends up in a material cost range of $40-150 €$ per $\mathrm{m}^{2}$. The highest share on the total costs is PET/ITO which is in the range of $38-51 \%$. This

a)

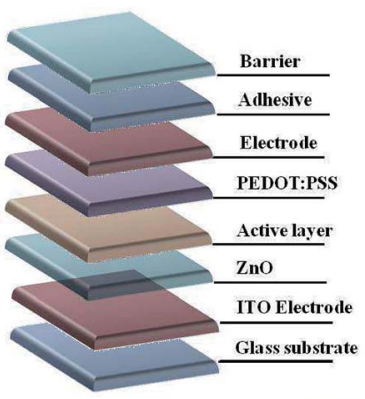

b)

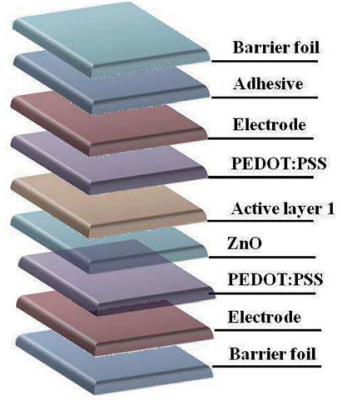

c)

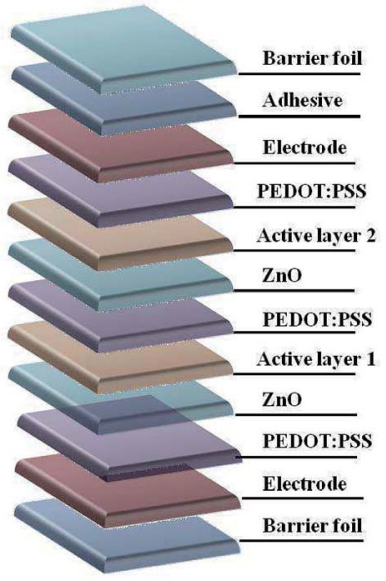

Fig. 2 Solar cell layer structures: (a) lab scale single cell, (b) R2R compatible single cell, and (c) R2R compatible tandem cell. 
is followed by the share for the active layer materials (21-27\%) and $\mathrm{Ag}(5-19 \%) .{ }^{13}$ Different strategies have to be used to lower especially the cost intensive layers: transparent electrode, barrier, back electrode and active layer materials. A very convincing concept to replace the expensive ITO is the use of the Flextrode substrate. ${ }^{20}$ This is a completely R2R processed low cost, transparent electrode concept. The current status for ITOfree, R2R processed and packaged large area devices on flexible substrates are a PCE of 3.5\% for single junctions and 1.3-2.2\% for tandem junctions. ${ }^{21-23}$ The certified efficiency for a fully R2R solution processed flexible tandem OPV module is $1.76 \%$ (active area $52 \mathrm{~cm}^{2}$ with eight tandem cells in series). We used the manufacturing data from those device types in the report. ${ }^{24} \mathrm{~A}$ detailed description of the materials, the processing and the resulting device efficiency is presented in ref. 24 . For single cells copolymers based on dithieno[3,2-b:2',3'-d]silole (DTS) and dithienylthiazolo[5,4-d]thiazole (TTz) were used in an all-solution roll-process. In the tandem devices poly-3-hexylthiophene (P3HT) and phenyl- $\mathrm{C}_{61}$-butyric acid methylester (PCBM) were used in both subcells. As mentioned before, for an industrial application a R2R compatible process has to be chosen.

\section{Results}

The starting point for our cost analysis is the R2R production of single and tandem devices. Real values of utilized material amounts and costs are employed to perform the cost analysis of the devices. These are based on the Flextrode substrates which were used instead of cost intensive electrodes like ITO. ${ }^{20}$ The second biggest share according to the analysis of Azzopardi was the active layer. ${ }^{13}$ Two different active layer materials are analyzed to identify the costs and the cost target of the active layer. The cost of a material is dominantly influenced by the produced quantity. Three different scenarios are addressed: current status (kW production regime), upscaling process (100 MW regime) and industrial processing (100 GW regime). For the current status supplier costs and experimentally achieved material consumption were used and thus represent what has already been achieved on a relatively small scale. For the upscaled scenarios cost trend estimations based on data from bulk suppliers have been made.

Besides the produced materials' quantity the electricity producing capacity is also important. Due to losses in the charge extraction the cell size of OPV devices is limited. Therefore OPV devices have to be divided into smaller, in series interconnected cells forming a module. The monolithic interconnection is a generally used concept in thin film module technology. This interconnection area does not contribute to the electricity generation. Therefore it should be as small as possible. The geometric fill factor (GFF) addresses this aspect. It is defined as the ratio of the active to the overall area of the module. The higher the GFF of produced modules the more effective the production yield.

In our experiments a GFF of $37 \%$ was achieved. The chosen layout was not optimized with respect to the GFF. In the upscaling and the industrial scenario higher values were used according to estimations and predictions for an optimized processed area coverage: $75 \%$ for the upscaling and $98 \%$ for the industrial scenario. ${ }^{25}$ The electrode materials are known to be one of the highest cost factors. In our models we used (a) Ag electrodes, (b) Ag front and aluminum back electrode and (c) carbon electrodes. Carbon has been proven to show comparable device performance. ${ }^{26}$ These electrode scenarios are based on a grid structure.

The tandem device architecture is a known concept to improve the device performance, but it also comprises more layers and is therefore more expensive and the challenges for maintaining higher technical yield become severe. An analysis of whether single or tandem devices should be used is discussed in a final section. In Scheme 1 a detailed analysis of the assumptions is given. Three different cases have been considered: current status, upscaling model and industrial model. For all three cases the device optimization potential, the price reduction potential and the material consumption potential are addressed. The material consumption potential refers to a potential of layout improvement which will result in a lower $\mathrm{Ag}$ consumption. The price reduction potentials refer to supplier estimations. The assumptions for the active layers materials are based on different expert opinions, necessary for a successful OPV technology.

\subsection{Cost analysis for single and tandem modules - state of the art: $k W$ production regime}

The first calculation is based on the so called 'freeOPV' module that has been reported and that is freely available to everybody. A detailed description of this module can be found in ref. 27. These flexible, ITO-free polymer solar cell modules are directly processed on a barrier foil. As active layer materials the commonly known P3HT and PCBM are used. Fig. 2(b) and (c) show the used layer structures for single and tandem devices. Table S1 in the ESI $\uparrow$ presents the used materials, the amounts and the corresponding cost for each layer of the single cell devices. Since in this analysis only real process data are utilized in the calculation a very exact determination of the end cost is achieved. For the freeOPV a material costs of $28.63 €$ per $\mathrm{m}^{2}$ resulted. For a covered active area of $37 \%$ and a module efficiency of $1.82 \%$ a cost of $4.28 €$ per $\mathrm{W}_{\mathrm{p}}$ is obtained for a $1000 \mathrm{~W}$ $\mathrm{m}^{-2}$ illumination. ${ }^{27}$ According to Fig. 1 which shows the share of total costs of the freeOPV modules for these cells the barrier foils and silver have the biggest share in the overall costs, followed by the active layer materials. In this manuscript we focus on material costs, since the processing costs depend on various parameters and therefore are only difficult to address and assume. Here labor costs as well as equipment is involved. For a rough estimation we assumed an average cost of $80 €$ per h for processing costs. By dividing the web speed which was used for each layer (reported in ref. 20 and 24) by this average cost the processing costs per layer can be calculated. The calculation is based on a R2R process described in ref. 20 and 24 with a substrate width of $305 \mathrm{~mm}$. For larger substrates the processing costs will be even lower. This is shown in the ESI in Table S14S17 and Fig. S8† for current state devices as the freeOPV single cells and tandem devices, as well as estimations for upscaling 


\begin{tabular}{|c|c|c|}
\hline Current status: & & \\
\hline $\begin{array}{l}\text { Device optimizat } \\
\text { cells) }\end{array}$ & ential (single and tandem & \\
\hline GFF & $37 \%$ & $37 \%$ \\
\hline Electrodes & $\mathrm{Ag}(2 € / g)$ & $\mathrm{Ag}(2 € / g)$ \\
\hline $\begin{array}{l}\text { Price reduction } \\
\text { potential }\end{array}$ & & \\
\hline Active layer & $\begin{array}{l}\text { P3HT }(45 € / g), \\
\operatorname{PCBM}(70 € / g)\end{array}$ & $\begin{array}{l}\text { MH301/MH306 (404 €/g), } \\
\text { PCBM }(70 € / g)\end{array}$ \\
\hline Adhesive & $0.6 € / g$ & $0.6 € / g$ \\
\hline Barrier foil & $6 € / g$ & $6 € / g$ \\
\hline $\mathrm{ZnO}$ & $0.48 € / \mathrm{mL}$ & $0.48 € / \mathrm{mL}$ \\
\hline PEDOT AI 4083 & $0.42 € / \mathrm{mL}$ & $0.42 € / \mathrm{mL}$ \\
\hline $\begin{array}{l}\text { Material consum } \\
\text { potential }\end{array}$ & & \\
\hline $\mathrm{Ag}$ & $0.53 \mathrm{~g} / \mathrm{m}^{2}$ (front electrode) & $0.53 \mathrm{~g} / \mathrm{m}^{2}$ (front electrode) \\
\hline
\end{tabular}

\begin{tabular}{|c|c|c|c|}
\hline \multicolumn{4}{|c|}{ Upscaling model: (assumption) } \\
\hline \multicolumn{4}{|c|}{$\begin{array}{l}\text { Device optimization potential (single and tandem } \\
\text { cells) }\end{array}$} \\
\hline GFF & $75 \%$ & $75 \%$ & $75 \%$ \\
\hline Electrodes & $\operatorname{Ag}(2 € / g)$ & $\mathrm{Ag}(2 € / \mathrm{g}), \mathrm{Al}(0.068 € / \mathrm{g})$ & Carbon $(0.135 € / g)$ \\
\hline \multicolumn{4}{|l|}{$\begin{array}{l}\text { Price reduction } \\
\text { potential }\end{array}$} \\
\hline Active layer & $\begin{array}{l}\text { MH301/MH306 }(20 € / g) \\
\text { PCBM }(20 € / g)\end{array}$ & $\begin{array}{l}\text { MH301/MH306 }(20 € / g) \\
\text { PCBM }(20 € / g)\end{array}$ & $\begin{array}{l}\text { MH301/MH306 }(20 € / g) \\
\text { PCBM }(20 € / g)\end{array}$ \\
\hline Adhesive & $0.1 € / g$ & $0.1 € / g$ & $0.1 € / g$ \\
\hline Barrier foil & $1 € / g$ & $1 € / g$ & $1 € / g$ \\
\hline $\mathrm{ZnO}$ & $0.01 € / \mathrm{mL}$ & $0.01 € / \mathrm{mL}$ & $0.01 € / \mathrm{mL}$ \\
\hline PEDOT AI 4083 & $0.20 € / \mathrm{mL}$ & $0.20 € / \mathrm{mL}$ & $0.20 € / \mathrm{mL}$ \\
\hline \multicolumn{4}{|c|}{$\begin{array}{l}\text { Material consumption } \\
\text { potential }\end{array}$} \\
\hline $\mathrm{Ag}$ & $0.26 \mathrm{~g} / \mathrm{m}^{2}$ (front electrode) & $0.26 \mathrm{~g} / \mathrm{m}^{2}$ (front electrode) & $0.26 \mathrm{~g} / \mathrm{m}^{2}$ (front electrode) \\
\hline
\end{tabular}

\begin{tabular}{|c|c|c|c|}
\hline \multicolumn{4}{|c|}{ Industrial model: (assumption) } \\
\hline \multicolumn{4}{|c|}{$\begin{array}{l}\text { Device optimization potential (single and tandem } \\
\text { cells) }\end{array}$} \\
\hline GFF & $98 \%$ & $98 \%$ & $98 \%$ \\
\hline Electrodes & $\operatorname{Ag}(2 € / g)$ & $\mathrm{Ag}(2 € / \mathrm{g}), \mathrm{Al}(0.068 € / \mathrm{g})$ & Carbon $(0.135 € / g)$ \\
\hline \multicolumn{4}{|l|}{$\begin{array}{l}\text { Price reduction } \\
\text { potential }\end{array}$} \\
\hline Active layer & $\begin{array}{l}\text { MH301/MH306 }(10 € / g) \\
\operatorname{PCBM}(10 € / g)\end{array}$ & $\begin{array}{l}\text { MH301/MH306 }(10 € / g), \\
\text { PCBM }(10 € / g)\end{array}$ & $\begin{array}{l}\text { MH301/MH306 }(10 € / g), \\
\text { PCBM }(10 € / g)\end{array}$ \\
\hline Adhesive & $0.1 € / g$ & $0.1 € / \mathrm{g}$ & $0.1 € / g$ \\
\hline Barrier foil & $1 € / g$ & $1 € / g$ & $1 € / g$ \\
\hline $\mathrm{ZnO}$ & $0.01 € / \mathrm{mL}$ & $0.01 € / \mathrm{mL}$ & $0.01 € / \mathrm{mL}$ \\
\hline PEDOT AI 4083 & $0.20 € / \mathrm{mL}$ & $0.20 € / \mathrm{mL}$ & $0.20 € / \mathrm{mL}$ \\
\hline \multicolumn{4}{|c|}{$\begin{array}{l}\text { Material consumption } \\
\text { potential }\end{array}$} \\
\hline $\mathrm{Ag}$ & $0.26 \mathrm{~g} / \mathrm{m}^{2}$ (front electrode) & $0.26 \mathrm{~g} / \mathrm{m}^{2}$ (front electrode) & $0.26 \mathrm{~g} / \mathrm{m}^{2}$ (front electrode) \\
\hline
\end{tabular}

Scheme 1 Process flow of the cost calculation.

and industrial scenarios under the assumption of higher speeds and more layers processed with an inline process. Fig. 3 shows that for an industrial scenario the assumed processing costs are negligible in comparison to the material costs. It is clear that processing cost presents a significant share of the cost at the laboratory scale but we underline that already at the present 


\section{INDUSTRIAL SCENARIO: TANDEM DEVICES}

- Material costs $\quad$ Processing costs

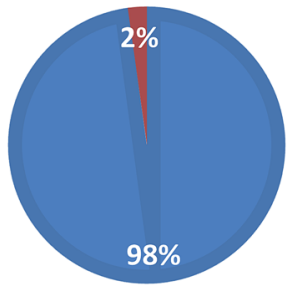

Fig. 3 Material and processing costs for an industrial scenario.

stage the overall cost is dominated by the material cost and upon upscaling the processing cost quickly decreases to an insignificant level and it is relatively safe to assume that the OPV technology is always dominated by material cost even on a relatively small industrial scale. Therefore, in the following only material costs are considered.

We analyzed two different models of active layer material combinations for tandem devices: (a) P3HT:PCBM in both subcells (low cost and PCE) and (b) MH301:PCBM and MH306:PCBM (high cost and PCE). For single cell devices P3HT:PCBM (low cost) and MH301:PCBM (high cost) are compared. The MH materials were synthesized at DTU as described previously. ${ }^{24,28}$ Table 1 summarizes the used materials, the material consumption and the resulting costs of P3HT:PCBM tandem modules in both sub-cells, ending up in an overall cost of $34.56 €$ per $\mathrm{m}^{2}$ for the tandem device. For the $\mathrm{MH}$ materials an estimated cost of $404 €$ per g was calculated. Table 2 shows a comparison of the active layer costs for the two chosen material systems. Besides the active layer donor materials and the donor:acceptor ratio, for the high cost scenario all other costs are identical to Table 1 . This leads to overall costs of $61.71 €$ per $\mathrm{m}^{2}$ for the high cost/PCE scenario. A detailed analysis of the costs is shown in Fig. S3 in the ESI. $\dagger$

As can be seen in Fig. S1 and S2 in the ESI $\uparrow$ the costs for the active layer determine the overall material costs of the produced modules, especially for the high cost material. In the cost structure that is achieved, the active materials account for $13 \%$ (single device) and 22\% (tandem device) of the overall cost in the case of active layer of P3HT:PCBM $(45 €$ per $g$ for P3HT and $70 €$ per $\mathrm{g}$ for PCBM). The share of the active layer is further increased for the high cost scenario resulting in $42 \%$ (single device) and $56 \%$ (tandem device) ( $404 €$ per $\mathrm{g}$ for the polymers and $70 €$ per $\mathrm{g}$ for the acceptor material).

A significant cost reduction of the active layer materials is necessary. The cost of a material can be dramatically reduced with higher capacities. In Section "3.2 Cost analysis single and tandem modules upscaling and industrial scenario: $100 \mathrm{MW}$ and $100 \mathrm{GW}$ production regime" the upscaling scenarios are considered. Here, the effect of higher capacities is addressed. Based on the resulting material amounts the material suppliers assumed the resulting costs which are presented in Scheme 1.

According to Azzopardi et al. the share of the material costs in the balance of module costs is between 65 and $81 \% .^{13}$ For further scenarios cost trend estimations based on experts' opinions have been made in relation to the used capacities.

An intelligent approach for increasing device performance based on low cost materials is the use of a ternary component which enhances the absorption spectrum of a matrix material in the near infra-red region. This approach has been intensively studied and is also feasible in tandem devices. ${ }^{29-32}$ The module costs of the upscaling and the industrial scenario are dependent

Table 1 Cost analysis current status low cost/PCE: P3HT:PCBM; tandem cell modules

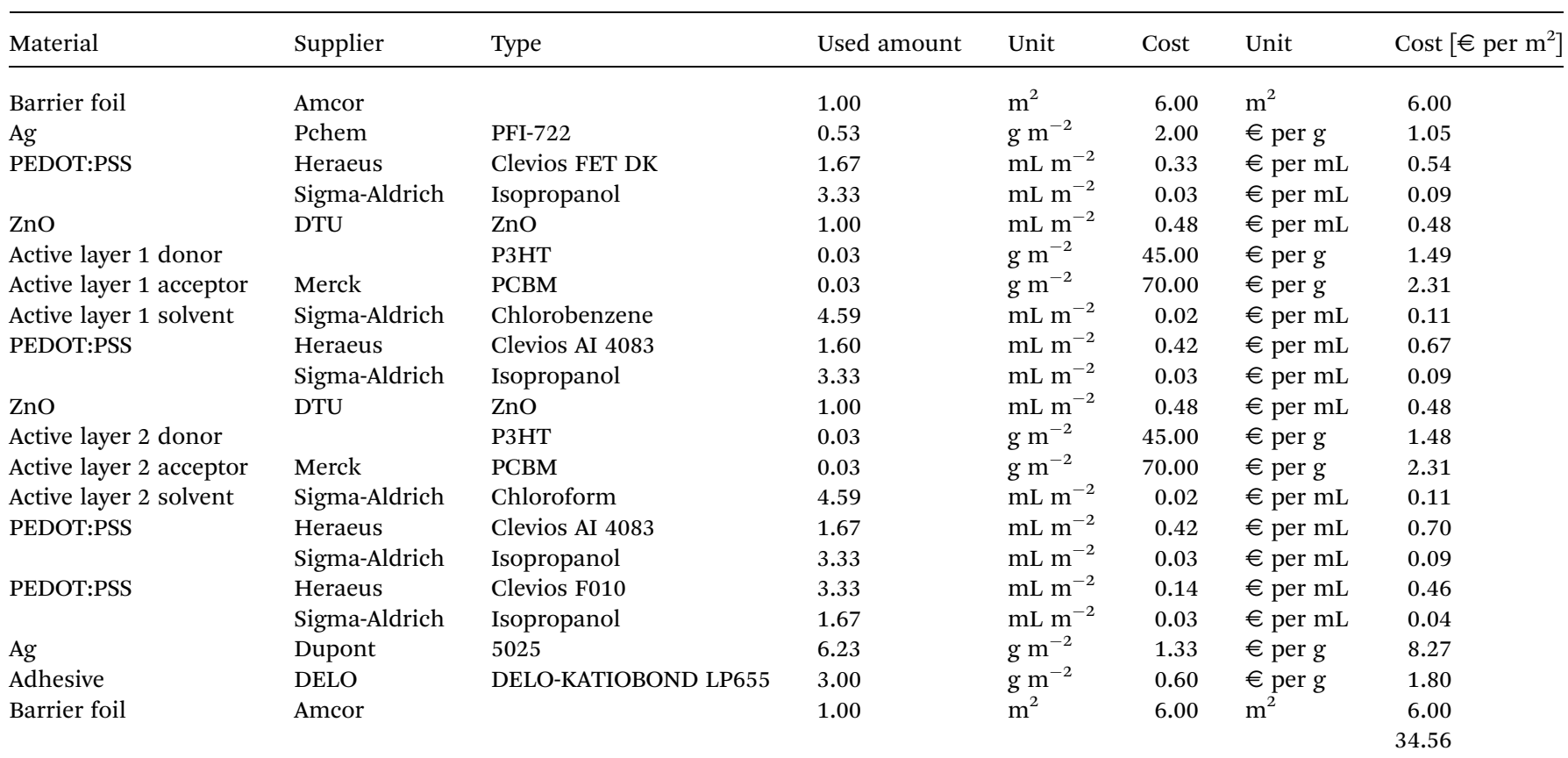


Table 2 Active layer costs and module costs for the three cost models: current status, upscaling and industrial scenario

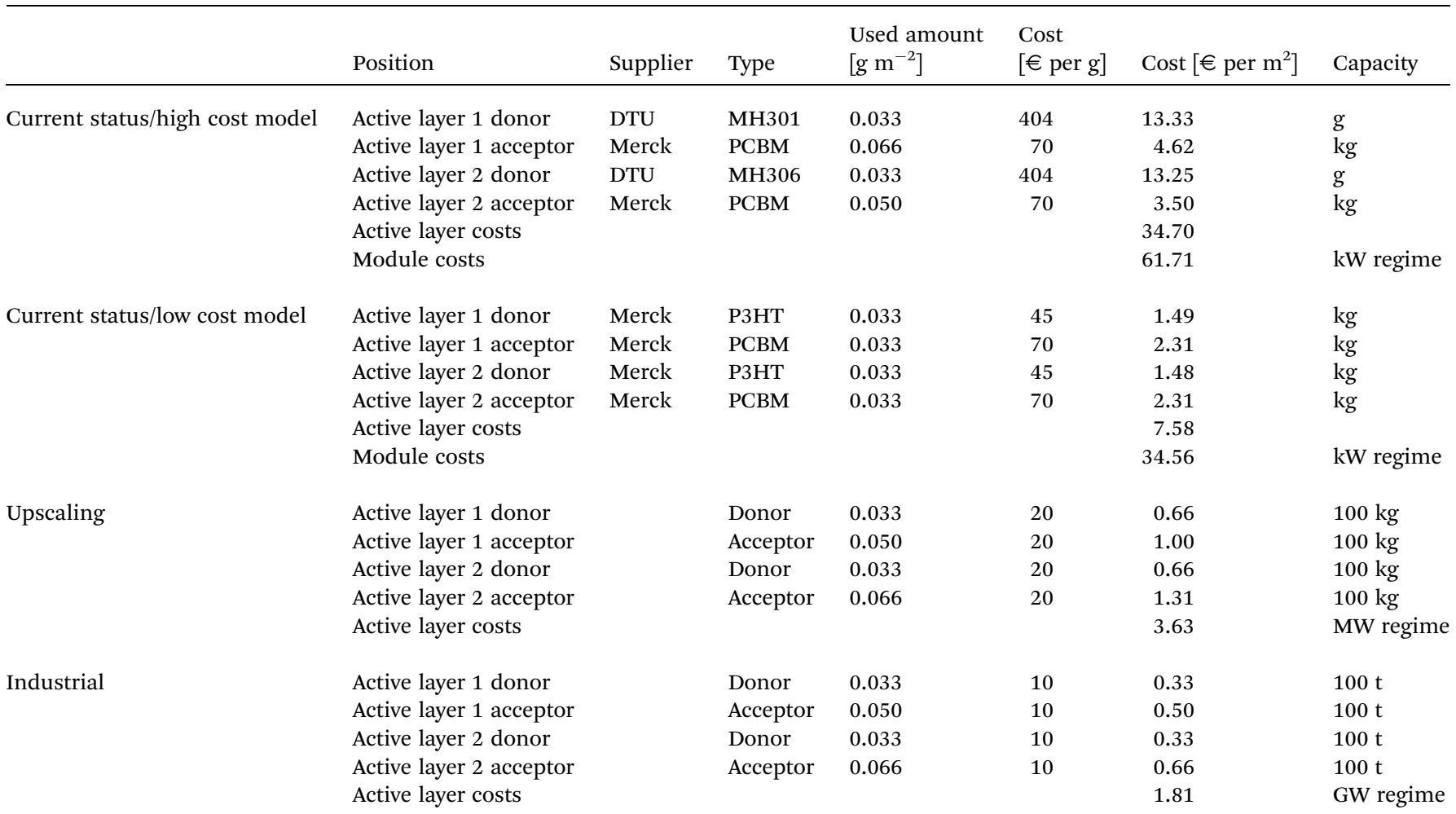

on further parameters, especially the electrode costs. Since these costs are especially addressed in the upscaling and industrial model no module costs are mentioned for these scenarios in Table 2.

The costs of inorganic PV is often calculated in $€$ per $\mathrm{W}_{\mathrm{p}}$. The calculation from $€$ per $\mathrm{m}^{2}$ to $€$ per $\mathrm{W}_{\mathrm{p}}$ is done by dividing the costs in $€$ per $\mathrm{m}^{2}$ by the illumination $\left(1000 \mathrm{~W} \mathrm{~m}^{-2}\right)$, an estimated power conversion efficiency (PCE) (2-10\%) and the geometrical fill factor (GFF) which gives the ratio of the active area to the processed area. In this calculation process costs are not reflected. For example for a material cost of $28.63 €$ per $\mathrm{m}^{2}$ and a PCE of $3 \%$ with a GFF of $37 \%$ a cost of $2.60 €$ per $W_{p}$ results. Fig. 4 shows the cost analysis of the currently available devices. Single devices and tandem devices are compared for both active layer cost scenarios. The GFF was in all cases $37 \%$. With increasing device efficiency the total costs can be significantly lowered. In these graphs only material costs are considered which are in the range of $28-62 €$ per $\mathrm{m}^{2}$. In the single junction low cost devices based on P3HT:PCBM are in the range of $3.9 €$ per $\mathrm{W}_{\mathrm{p}}$ to $0.8 €$ per $\mathrm{W}_{\mathrm{p}}$. In this case P3HT:PCBM is used as a representative active layer material combination with potential to achieve higher device efficiencies.

Generally, the efficiency of tandem cells is expected to be higher. This aspect is addressed in Section 3.3 by comparing a $40 \%$ higher efficiency of tandem devices to single devices. In Fig. 4 and 5 the resulting costs for fixed efficiencies are assumed. These vary between $2-10 \%$ for both kinds of device architecture. As described in the state of the art section currently R2R processed, ITO free and packaged large area devices on flexible substrates reach a PCE of $3.5 \%$ for single junctions and 1.3-2.2\% for tandem junctions which shows that the selected range for the estimations is realistic.

Besides the used materials also the processing can significantly influence the costs. A decisive parameter is the active area. Fig. 4(b) shows the influence of the GFF for the freeOPV with an overall cost of $28.63 €$ per $\mathrm{m}^{2}$. A dramatic cost reduction is possible for an increased GFF from the current status, 37\% (not optimized) to already $50 \%$ and $75 \%$ which can be achieved by an optimized printing process. For GFFs above $90 \%$ a laser ablation structuring process is necessary which we reported as being compatible with a R2R process. ${ }^{25,33}$

In this section we present a cost calculation for $\mathrm{R} 2 \mathrm{R}$ processed encapsulated, flexible ITO- and vacuum-free OPV modules for both single and tandem junctions based on experimental material consumption data on a pilot scale. The material cost ranges between $28-62 €$ per $\mathrm{m}^{2}$, depending on the active layer material used and the number of active layers in the device. This corresponds to $0.8-8.4 €$ per $\mathrm{W}_{\mathrm{p}}$ for a PCE of 2$10 \%$. In comparison to established technologies a further cost decrease is necessary for a competitive market position of OPV devices. By using scale up effects the potential of a matured OPV production will be illustrated.

\subsection{Cost analysis of single and tandem modules for the upscaling and industrial scenario: $100 \mathrm{MW}$ and $100 \mathrm{GW}$ production regimes}

In addition to the current state cost analysis, projections of lower cost targets are analyzed. In the following different scenarios for cost reduction are used. The used amounts of 
a) Current scenario

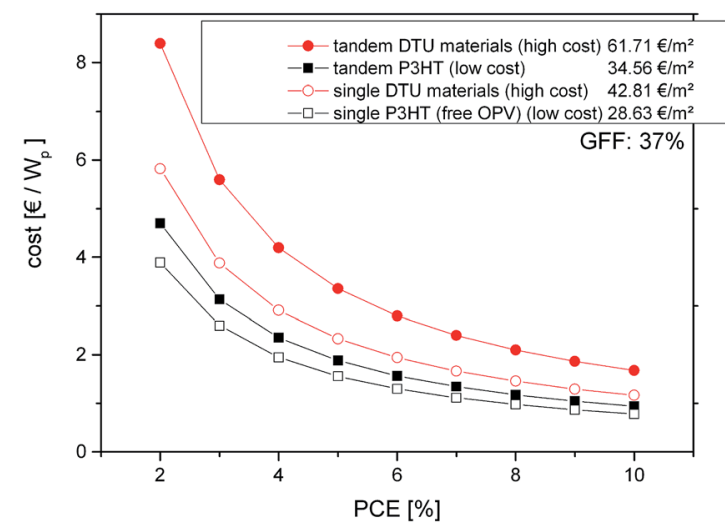

b) Influence GFF

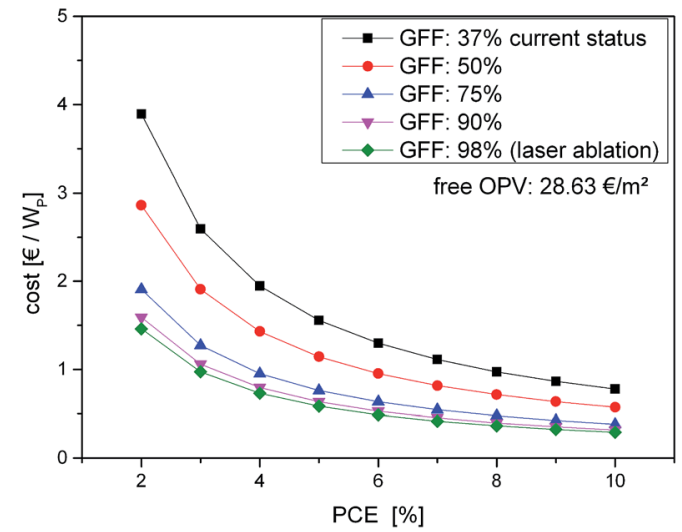

Fig. 4 a) Cost analysis - as a function of PCE diagram for single and tandem cell modules for a GFF of $37 \%$. (b) Cost model - influence of the geometrical fill factor on the overall cost for an assumed overall cost of the freeOPV costs.

materials for the active layer, including the donor/acceptor ratio for upscaling and the industrial scenario are based on the material systems MH301:PCBM and MH306:PCBM for single and tandem devices.

For a reduction of the share of the active layer two different scenarios have been evaluated based on a $100 \mathrm{MW}$ production in an upscaling scenario and a $100 \mathrm{GW}$ production in an industrial scenario.

Based on experts' opinions the cost trends of $20 €$ per $\mathrm{g}$ for the upscaling scenario and $10 €$ per $\mathrm{g}$ for the industrial scenario have been chosen. Here, higher production capacities are necessary which can be easily calculated. For an energy output of $100 \mathrm{MW}$ under the assumption of a module with 5\% PCE $\left(50 \mathrm{~W} \mathrm{~m}^{-2}\right)$ a module area of $2 \times 10^{6} \mathrm{~m}^{2}$ has to be processed. Using an active material amount of $0.2 \mathrm{~g} \mathrm{~m}^{-2}, 427 \mathrm{~kg}$ of the active layer material is needed for this process. For a $100 \mathrm{GW}$ production output a module area of $2 \times 10^{9} \mathrm{~m}^{2}$ has to be processed, resulting in a necessity of $427 \mathrm{t}$ of the active layer material.

One of the cost intensive layers is Ag. Carbon as an alternative material was proven to be able to replace $\mathrm{Ag} .{ }^{21}$ Further, a scenario for an aluminium replacement of the back electrode is a) Upscaling scenario

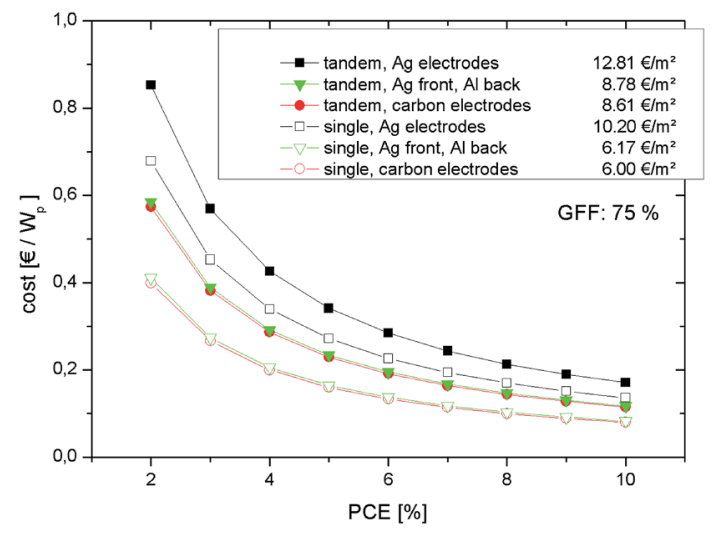

b) Industrial scenario

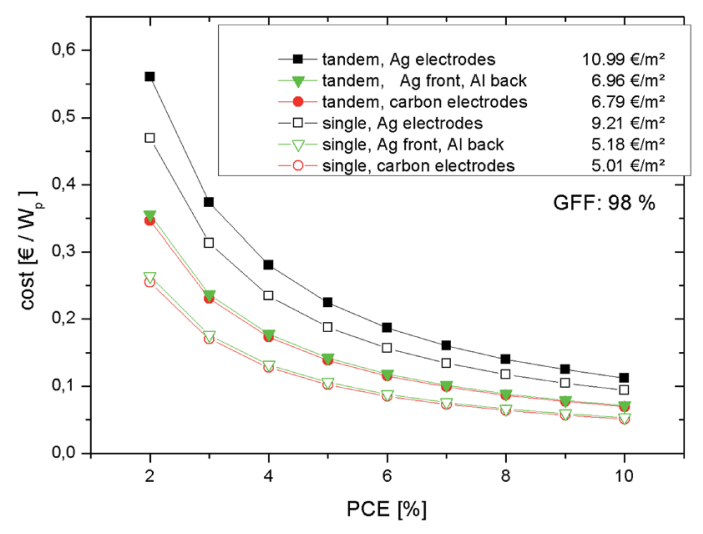

Fig. 5 Cost models for a comparison of tandem and single devices for (a) upscaling scenario (75\% GFF) and (b) industrial scenario (98\% GFF) and different electrode models: Ag electrodes, Ag front/Al back electrode, and carbon electrodes.

shown. The cost calculation of the aluminium paste only includes the material consumption for lab scale production and is contrary to the $\mathrm{Ag}$ paste and not to a commercial ink. Table 3 summarizes the cost analysis of an upscaling scenario for $\mathrm{Ag}$ electrodes. In this scenario a lower consumption of materials and a lower cost are included. The lower material consumption results from process optimization steps and the lower material costs are related to higher production capacities, leading to an overall material cost of $12.81 €$ per $\mathrm{m}^{2}$ for tandem devices with Ag electrodes. Table 4 shows the comparison of different electrode scenarios. A cost reduction of $77 \%$ for the electrodes could be achieved for the replacement of $\mathrm{Ag}$ with aluminium as the back electrode. This would be even more dramatic for carbon replacements (90\%).

Fig. 5(a) shows the cost model of the upscaling model for different efficiencies. Single cells and tandem cells are compared for all three electrode scenarios. A GFF of $75 \%$ was assumed in all cases. For the active layer materials costs of $20 €$ per $\mathrm{g}$ for the donor and the acceptor have been assumed, according to Table 2 . This results in an overall active layer cost of $3.63 €$ per $\mathrm{m}^{2}$. A detailed cost analysis of each scenario can be found in the ESI. $\uparrow$ Compared to Fig. 4(a) (current status scenario) the resulting costs per $\mathrm{W}_{\mathrm{p}}$ would be considerably 
Table 3 Cost analysis upscaling scenario: Ag electrodes; tandem cell modules

\begin{tabular}{|c|c|c|c|c|c|c|c|}
\hline Material & Supplier & Type & Used amount & Unit & Cost & Unit & Cost $\left[€\right.$ per $\left.\mathrm{m}^{2}\right]$ \\
\hline Barrier foil & & & 1.00 & $\mathrm{~m}^{2}$ & 1.00 & $\mathrm{~m}^{2}$ & 1.00 \\
\hline $\mathrm{Ag}$ & Pchem & PFI-722 & 0.26 & $\mathrm{~g} \mathrm{~m}^{-2}$ & 2.00 & $€$ per $g$ & 0.53 \\
\hline & Sigma-Aldrich & Isopropanol & 3.33 & $\mathrm{~mL} \mathrm{~m} \mathrm{~m}^{-2}$ & 0.03 & $€$ per $\mathrm{mL}$ & 0.09 \\
\hline $\mathrm{ZnO}$ & DTU & $\mathrm{ZnO}$ & 1.00 & $\mathrm{~mL} \mathrm{~m}^{-2}$ & 0.01 & $€$ per $\mathrm{mL}$ & 0.01 \\
\hline Active layer 1 donor & & MH301 based calculation & 0.033 & $\mathrm{~g} \mathrm{~m}^{-2}$ & 20.00 & $€$ per $\mathrm{g}$ & 0.66 \\
\hline \multirow[t]{2}{*}{ PEDOT } & Heraeus & PEDOT AI 4083 & 1.60 & $\mathrm{~mL} \mathrm{~m} \mathrm{~m}^{-2}$ & 0.20 & $€$ per $\mathrm{mL}$ & 0.32 \\
\hline & Sigma-Aldrich & Isopropanol & 3.33 & $\mathrm{~mL} \mathrm{~m} \mathrm{~m}^{-2}$ & 0.03 & $€$ per $\mathrm{mL}$ & 0.09 \\
\hline $\mathrm{ZnO}$ & DTU & $\mathrm{ZnO}$ & 1.00 & $\mathrm{~mL} \mathrm{~m}^{-2}$ & 0.01 & $€$ per $\mathrm{mL}$ & 0.01 \\
\hline Active layer 2 donor & & MH6 based calculation & 0.033 & $\mathrm{~g} \mathrm{~m}^{-2}$ & 20.00 & $€$ per $\mathrm{g}$ & 0.66 \\
\hline Active layer 2 acceptor & & PCBM based calculation & 0.050 & $\mathrm{~g} \mathrm{~m}^{-2}$ & 20.00 & $€$ per $\mathrm{g}$ & 1.00 \\
\hline Active layer 2 solvent & Sigma-Aldrich & Chloroform & 4.59 & $\mathrm{~mL} \mathrm{~m}^{-2}$ & 0.02 & $€$ per $\mathrm{mL}$ & 0.11 \\
\hline $\mathrm{Ag}$ & Dupont & 5025 & 3.11 & $\mathrm{~g} \mathrm{~m}^{-2}$ & 1.33 & $€$ per $g$ & 4.13 \\
\hline Adhesive & DELO & DELO-KATIOBOND LP655 & 3.00 & $\mathrm{~g} \mathrm{~m}^{-2}$ & 0.10 & $€$ per $\mathrm{g}$ & 0.30 \\
\hline \multirow[t]{2}{*}{ Barrier foil } & & & 1.00 & $\mathrm{~m}^{2}$ & 1.00 & $\mathrm{~m}^{2}$ & 1.00 \\
\hline & & & & & & & 12.81 \\
\hline
\end{tabular}

Table 4 Electrode costs and module costs for the three cost models: (a) Ag front electrodes, (b) Ag front/Al back electrodes, and (c) carbon electrodes. In all models a lower consumption of the electrode material is assumed, according to Table 3

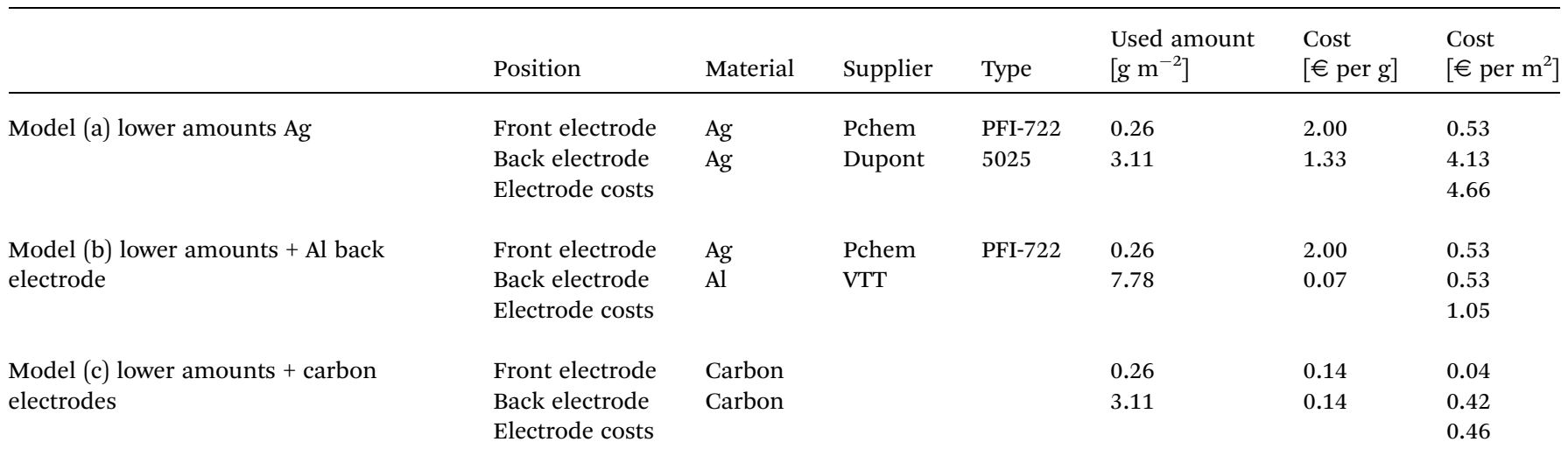

lower. The resulting costs range between 0.08 to $0.9 €$ per $\mathrm{W}_{\mathrm{p}}$. These scenarios already illustrate the potential for a preindustrial OPV production for a capacity of $100 \mathrm{MW}$.

For an industrially applicable model a $100 \mathrm{GW}$ production regime is used. This capacity lowers again the material costs, especially for the active layer to an assumed value of $10 €$ per $g$ for the donor and the acceptor, according to Table 2. This results in an overall active layer cost of $1.81 €$ per $\mathrm{m}^{2}$. Further process optimization allows a GFF of $98 \%$. A detailed cost analysis of this model is shown in Table 5 (for carbon electrodes and tandem devices). Further cost analyses are presented in the ESI. $\dagger$ Compared to the upscaling scenario a continuous cost reduction was used, leading to cost ranges between $0.05-0.6 €$ per $W_{p}$ as can be seen in Fig. 5(b). Due to lower active layer material costs and a higher GFF the cost range spreads between 5.01 and $10.99 €$ per $\mathrm{m}^{2}$ for the analyzed scenarios. Fig. 6(a) describes the cost reduction potential of each layer. The different assumptions for the electrode materials are separately presented in Fig. 6(b). The active layer donor material has the highest potential for a cost reduction. Favoring carbon as the electrode material would show a significant advantage compared to the competitive electrode materials.

In summary, an OPV technology including material usage with industrial quantities would lead to cost scenarios significantly below $0.6 €$ per $\mathrm{W}_{\mathrm{p}}$. For a $10 \%$ technology all scenarios show a cost below $0.15 €$ per $\mathrm{W}_{\mathrm{p}}$ which is a strong argument for fostering research thrust in scale-up and industrialization.

\subsection{Further aspects}

According to the reported prediction it is expected that a PCE improvement by $40 \%$ can be obtained for tandem solar cells compared to the optimized single-junction solar cells 
Table 5 Cost analysis industrial production regime: carbon electrode scenario; tandem cell modules

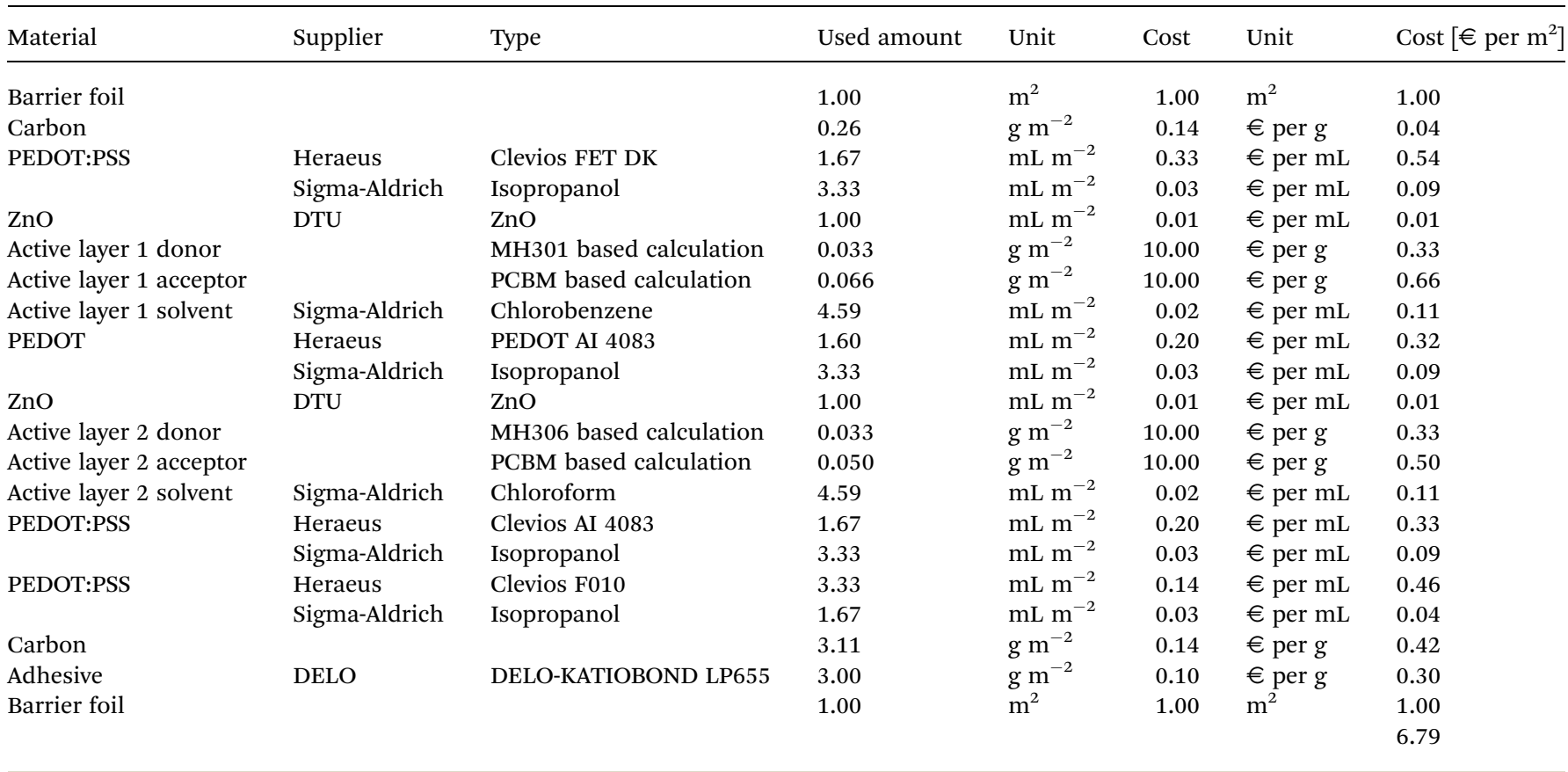

a)

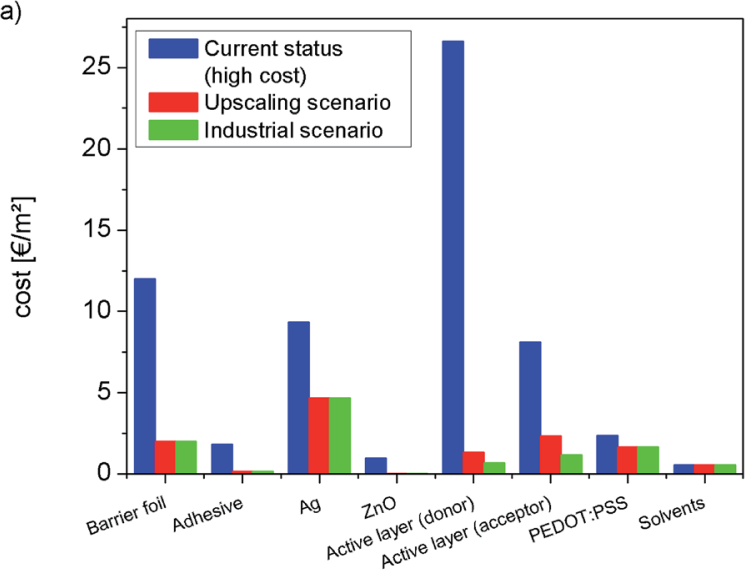

b)

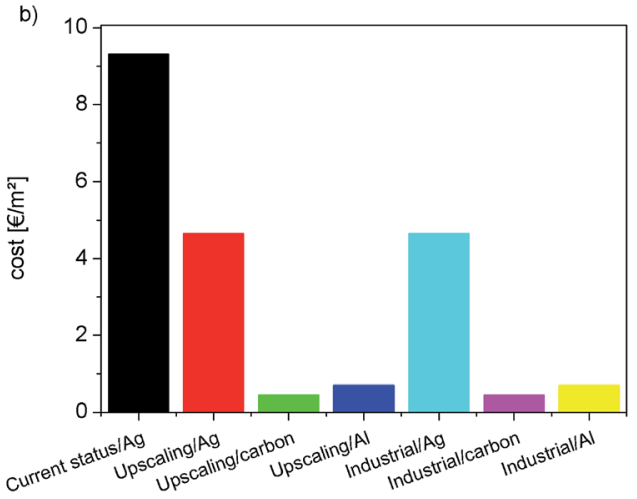

Fig. 6 (a) Cost reduction potential of separate layers of tandem devices for the three production capacity scenarios. (b) Cost potential for different electrode material scenarios. (assuming an identical technical yield). ${ }^{1}$ The technical yield for standard single junctions is demonstrated to be exceptionally high (99.9993\% shown in ref. 34) and it is clear that the potentially higher performance of the tandem architecture is only meaningful if the technical yield can be maintained. Based on results of ref. 24 we show on the manufacture of the tandem OPV how important technical yield is and how it depends on the processing method. Fig. 7 shows the technical yield of two rollto-roll processed runs (a) a discrete process and (b) an inline processing. In the best cases the tandem junction yield with the discrete process achieved a yield of $28.8 \%$ (576/2000), whereas $96.6 \%(1938 / 2000)$ was reached for inline processing. The module yield resulted in $0 \%$ for the discrete processed and $80 \%$ for the inline processed tandem modules. We thus assume that
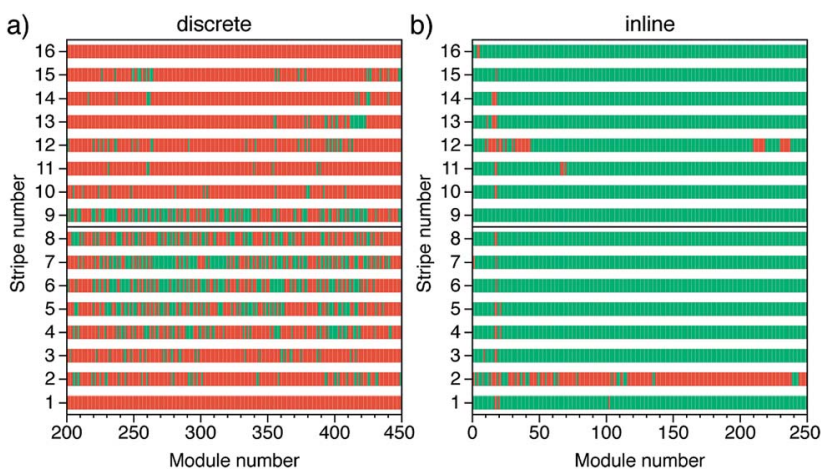

Fig. 7 Technical yield shown for two roll-to-roll processing runs based on results of ref. 24: (a) discrete processing and (b) inline processing. The red colour indicates that the junction is not a functional tandem junction, whereas the green colour represents typical a fully functional tandem junction. 


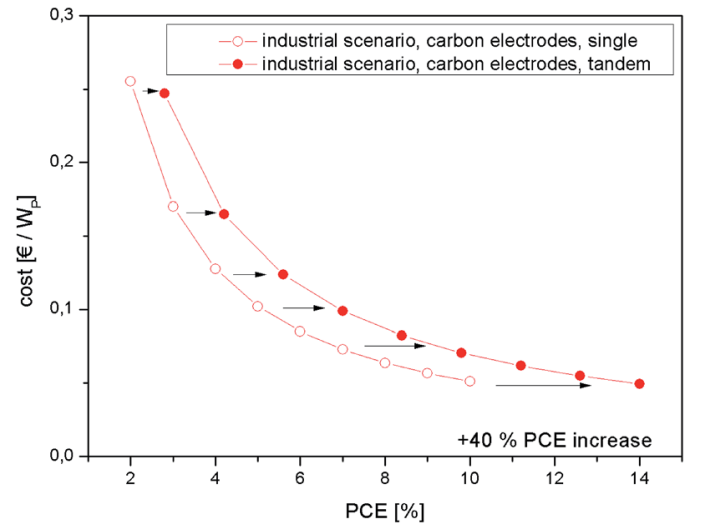

Fig. 8 Cost model for a comparison of tandem single devices with expected PCE increase of $40 \%$ for tandem devices in comparison to single devices. Industrial scenario - carbon electrode models (an identical technical yield is assumed).

the technical difficulty of maintaining a high technical yield for the tandem devices can be overcome and it is assumed that this would be realized in the upscaled and industrial scenario.

Fig. 8 includes this prediction and compares the cost model for single cells with the cost model for tandem devices with a $40 \%$ higher PCE for the carbon electrode models in the industrial processing scenario. The curve for tandem devices is shifted to higher efficiencies, due to the assumed $40 \%$ higher PCE. For example for $2 \%$ PCE in single devices, $2.8 \%$ in tandem devices is reached. This also results in a lower cost per $\mathrm{W}_{\mathrm{p}}$ : instead of dividing the cost per $\mathrm{m}^{2}$ by $20 \mathrm{~W} \mathrm{~m}^{-2}$ the value is divided by $28 \mathrm{~W} \mathrm{~m}^{-2}$. In the case of tandem devices the cost in $€$ per $\mathrm{m}^{2}$ is higher than the single junction devices. But with an expected $40 \%$ gain in PCE the higher PCE will compensate the higher cost which is visible in the comparison of $€$ per $\mathrm{W}_{\mathrm{p}}$, also illustrated in Fig S7 in the ESI. $\dagger$ These comparable costs $(€$ per $\mathrm{W}_{\mathrm{p}}$ ), but higher device efficiencies make tandem devices a promising technique, whenever the full potential of tandems is reached.

Besides the material cost another factor is the cost of installation. Compared to IPV modules the use of flexible substrates enables a very quick installation and de-installation of the modules as shown experimentally on a large scale. ${ }^{34,35}$ Installation velocities of $>100 \mathrm{~m} \mathrm{~min}^{-1}$ and de-installation velocities of $>200 \mathrm{~m} \mathrm{~min}^{-1}$ have been realized which illustrates the advantage of the OPV technology.

\section{Conclusion}

We demonstrated a cost analysis for OPV single and tandem modules based on three different scenarios: current status (kW production), upscaling process (100 MW production) and industrial application (100 GW production). Based on the current status of freeOPV P3HT:PCBM single cell modules and tandem modules with two different active layer donor materials (low and high cost/PCE scenario) a cost of $1-8.4 €$ per $\mathrm{W}_{\mathrm{p}}$ is achieved, depending on the achieved power conversion efficiency, material choice and structure. The main shares of the overall cost have been identified to be the active layer materials, the electrodes and the barrier foils. In an upscaling scenario, a higher geometrical fill factor and lower overall costs are achieved by assuming higher capacities and alternative electrode materials. This has been expanded further to an industrial processing scenario which leads to an expected module cost in the range of $0.05-0.6 €$ per $\mathrm{W}_{\mathrm{p}}$, depending on the efficiency, material choice and structure. These scenarios prove that OPV is a competitive energy technology that not only outperforms IPV but also other energy technologies such as wind, hydro and biomass.

\section{Author contributions}

N. L., G. D. S., T. A., F. M., R. R. S., M. J., M. H., M. L., N. M., C. J. B. and F. C. K. developed the device architecture, performed the experimental realization on various printing setups and proved its reproducibility. A. S. and D. G. prepared the PH1000, AL4083 and F010 PEDOT:PSS formulations and its cost calculation. K. K. and D. L. prepared the adhesive formulation and its cost calculation. F. C. K. prepared the ZnO formulation and its cost calculation. M. Vi, M. Vä and S. N. developed the aluminium paste formulation and its cost calculation. F. C. K., M. H., R. R. S., and M. J. developed the R2R process. N. L., F. M., N. L., M. L., A. S., D. G., K. K., S. B., O. L., S. N., M. Vä., and M. Vi. all contributed to one of the R2R printing runs in January 2014. C. J. B. and F. C. K. conceived the experiments. M. H. prepared the illustrations and F. M. wrote the manuscript. All authors proof read the manuscript.

\section{Acknowledgements}

The authors gratefully acknowledge the support of the European Commission as part of the seventh framework programme (ICT) collaborative project ROTROT (grant no. 288565), the Cluster of Excellence 'Engineering of Advanced Materials' at the University of Erlangen-Nuremberg which is funded by the German Research Foundation (DFG) within the framework of its 'Excellence Initiative' and the project of Solar Technologies go Hybrid (SolTech). Furthermore, the authors acknowledge the solar factory of the future as part of the energy campus Nuremberg (EnCN), which is supported by the Bavarian state government. This work has been partially supported by the Danish Ministry of Science, Innovation and Higher Education under a Sapere Aude Top Scientist grant (no. DFF - 133500037A), an Elite Scientist grant (no. 11-116028) and Energinet.dk (project no. 10728 and 12144).

\section{Notes and references}

1 R. R. Søndergaard, M. Hösel, D. Angmo, T. T. Larsen-Olsen and F. C. Krebs, Mater. Today, 2012, 15, 36-49.

2 R. R. Søndergaard, M. Hösel and F. C. Krebs, J. Polym. Sci., Part B: Polym. Phys., 2013, 51, 16-34.

3 F. C. Krebs, M. Jørgensen, K. Norrman, O. Hagemann, J. Alstrup, T. D. Nielsen, J. Fyenbo, K. Larsen and J. Kristensen, Sol. Energy Mater. Sol. Cells, 2009, 93, 422-441. 
4 G. Dennler, M. C. Scharber, T. Ameri, P. Denk, K. Forberich, C. Waldauf and C. J. Brabec, Adv. Mater., 2008, 20, 579-583.

5 G. Dennler, M. C. Scharber and C. J. Brabec, Adv. Mater., 2009, 21, 1323-1338.

6 T. Ameri, G. Dennler, C. Waldauf, P. Denk, K. Forberich, M. C. Scharber, C. J. Brabec and K. Hingerl, J. Appl. Phys., 2008, 103, 084506.

7 T. Ameri, N. Li and C. J. Brabec, Energy Environ. Sci., 2013, 6, 2390-2413.

8 N. Li, T. Stubhan, D. Baran, J. Min, H. Wang, T. Ameri and C. J. Brabec, Adv. Energy Mater., 2013, 3, 301-307.

9 N. Li, D. Baran, K. Forberich, M. Turbiez, T. Ameri, F. C. Krebs and C. J. Brabec, Adv. Energy Mater., 2013, 3, 1597-1605.

10 A. L. Roes, E. A. Alsema, K. Blok and M. K. Patel, Progress in Photovoltaics: Research and Applications, 2009, 17, 372-393.

11 J. Kalowekamo and E. Baker, Sol. Energy, 2009, 83, 12241231.

12 F. C. Krebs, T. Tromholt and M. Jørgensen, Nanoscale, 2010, 2, 873-886.

13 B. Azzopardi, C. J. M. Emmott, A. Urbina, F. C. Krebs, J. Mutale and J. Nelson, Energy Environ. Sci., 2011, 4, 37413753.

14 C. J. Mulligan, M. Wilson, G. Bryant, B. Vaughan, X. Zhou, W. J. Belcher and P. C. Dastoor, Sol. Energy Mater. Sol. Cells, 2014, 120, 9-17.

15 G. Dennler and C. J. Brabec, Socio-economic impact of lowcost PV technologies, in Organic Photovoltaics, ed. C. Brabec, V. Dyakonov and U. Scherf, Wiley-VCH, Weinheim, Germany, 2008, pp. 531-567.

16 M. A. Green, K. Emery, Y. Hishikawa, W. Warta and E. D. Dunlop, Progress in Photovoltaics: Research and Applications, 2014, 22, 1-9.

17 J. You, L. Dou, K. Yoshimura, T. Kato, K. Ohya, T. Moriarty, K. Emery, C. C. Chen, J. Gao, G. Li and Y. Yang, Nat. Commun., 2013, 4, 1446.

18 C. Emmott, A. Urbina and J. Nelson, Sol. Energy Mater. Sol. Cells, 2012, 97, 14-21.

19 N. Espinosa, R. Garcia-Valverde, A. Urbina, F. Lenzmann, M. Manceau, D. Angmo and F. C. Krebs, Sol. Energy Mater. Sol. Cells, 2012, 97, 3-13.

20 M. Hösel, R. R. Søndergaard, M. Jørgensen and F. C. Krebs, Energy Technol., 2013, 1, 102-107.
21 J. E. Carlé and F. C. Krebs, Sol. Energy Mater. Sol. Cells, 2013, 119, 309-310.

22 M. Helgesen, J. E. Carlé and F. C. Krebs, Adv. Energy Mater., 2013, 3, 1664-1669.

23 T. R. Andersen, H. F. Dam, B. Andreasen, M. Hösel, M. V. Madsen, S. A Gevorgyan, R. R. Søndergaard, M. Jørgensen and F. C. Krebs, Sol. Energy Mater. Sol. Cells, 2014, 120, 735-743.

24 T. R. Andersen, H. F. Dam, M. Hösel, M. Helgesen, J. E. Carlé, T. T. Larsen-Olsen, S. A. Gevorgyan, J. W. Andreasen, J. Adams, N. Li, F. Machui, T. Ameri, N. Lemaître, M. Legros, A. Scheel, D. Gaiser, K. Kreul, S. Berny, O. R. Lozmann, S. Nordman, M. Välimäki, M. Vilkman, R. R. Søndergaard, M. Jørgensen, C. J. Brabec and F. C. Krebs, Energy Environ. Sci., DOI: 10.1039/ c4ee01223b.

25 P. Kubis, N. Li, T. Stubhan, F. Machui, G. J. Matt, M. M. Voigt and C. J. Brabec, Progress in Photovoltaics: Research and Applications, 2013, DOI: 10.1002/pip.2421.

26 T. T. Larsen-Olsen, R. R. Søndergaard, K. Norrman, M. Jørgensen and F. C. Krebs, Energy Environ. Sci., 2012, 5, 9467-9471.

27 F. C. Krebs, M. Hösel, M. Corazza, B. Roth, M. V. Madsen, S. A. Gevorgyan, R. R. Søndergaard, D. Karg and M. Jørgensen, Energy Technol., 2013, 1, 378-381.

28 J. E. Carlé, M. Helgesen, M. V. Madsen, E. Bundgaard and F. C. Krebs, J. Mater. Chem. C, 2014, 2, 1290-1297.

29 T. Ameri, T. Heumüller, J. Min, N. Li, G. Matt, U. Scherf and C. J. Brabec, Energy Environ. Sci., 2013, 6, 1796-1801.

30 T. Ameri, P. Khoram, T. Heumüller, D. Baran, F. Machui, A. Troeger, V. Sgobba, D. M. Guldi, M. Halik, S. Rathgeber, U. Scherf and C. J. Brabec, submitted.

31 T. Ameri, J. Min, J. N. Li, F. Machui, D. Baran, M. Forster, K. J. Schottler, D. Dolfen, U. Scherf and C. J. Brabec, Adv. Energy Mater., 2012, 2, 1198-1202.

32 N. Li, T. Stubhan, N. A. Luechinger, S. C. Halim, G. J. Matt, T. Ameri and C. J. Brabec, Org. Electron., 2012, 13, 2479-2484.

33 P. Kubis, L. Lucera, F. Machui, G. Spyropolous, J. Cordero, A. Frey, J. Kaschta, M. Voigt, G. Matt and C. J. Brabec, Org. Electron., DOI: 10.1016/j.orgel.2014.06.006.

34 F. C. Krebs, N. Espinosa, M. Hösel, R. R. Søndergaard and M. Jørgensen, Adv. Mater., 2014, 26, 29-39.

35 N. Espinosa, M. Hösel, M. Jørgensen and F. C. Krebs, Energy Environ. Sci., 2014, 7, 855-866. 